\title{
Ergonomics and Tri Hita Karana Conception in Balinese Traditional Houses
}

\author{
INYOMANARTAYASA \\ Interior Design, Faculty of Art and Design, \\ The Indonesia Institute of the Art Denpasar, Indonesia
}

\begin{abstract}
Tri Hita Karana is the concept of three things that can lead to happiness, which consist of the relationship of human beings with God, amongst human beings, and the relationship of human beings with the environment, which is embodied in the circulation, the design space forming element, the supporting build a space, design of facilities, utilities and decoration. The study of ergonomics on traditional residential houses in Bali focuses on task elements, organization and environment. The task examines how the facilities are created based on anthropometric and activity flow. The organization studies about traditional Balinese buildings layout in terms of organization of space, which resulted in a large scale, function space and circulation space. Environment review the two sides, firstly is physical environment, namely: the use of circulation, lighting and handling the existing season every year, and secondly is the social environment, namely: religion, beliefs, norms and others. There are similarities between Ergonomics and Tri Hita Karana, therefore this study intend to it. It is conducted by using qualitative descriptive analysis with the application of Tri Hita Karana concept on traditional Balinese buildings and also accompanied with ergonomic values based on te ape ape ape ape ape ape ape ape ape ape ape ape ape ape ape appose of this writing is to observe whether the ergonomics and Tri Hita Karana have similar views in the embodiment of traditional Balinese houses. In the end of the discussion we can conclude that the embodiment of traditional Balinese residential buildings has to be considered on the relationship of human beings with God and also the relationship of human being with the environment. It is also includes a consideration in ergonomics consists of: task, organization and environment; and it is found out that in the concept of Tri Hita Karana has similarities with the concept of ergonomics on traditional Balinese houses.
\end{abstract}

Keywords: Ergonomics; Tri Hita Karana

The study is aim to observe the traditional Balinese houses pattern, which is analyzed from ergonomics point of view with the concept of Tri Hita Karana. Tri Hita Karana is the concept of three things that can lead to happiness, which consist of relationship of human beings with God, amongst human beings and the relationship between human beings with environment, which is embodied in the circulation, the design space forming element, the supporting space building, facilities design, utilities and decoration. The study of ergonomics on traditional residential houses in Bali focuses on task elements, organization and environment. The task will examine how the facilities were created based on anthropometric, activity flow. The organization studies about traditional Balinese buildings layout in terms of organization of space, which resulted in a large, function and circulation space. Environment review the two sides, firstly is physical environment, namely: the use of circulation, lighting and handling the existing season every year, and secondly is the social environment, namely: religion, beliefs, norms and others. There are similarities between Ergonomics and Tri Hita Karana, therefore this study will intend to it. It is conducted by using qualitative descriptive analysis with the application of Tri Hita Karana conception in traditional Balinese houses and also accompanied with ergonomic values based on the subject of the task, and environmental organizations.

There are many similarities of both mentioned above. Therefore this study will review several matters 
which relate to the two concepts, such as the need of ergonomics on traditional Balinese residential houses, the similarities of Tri Hita Karana concept application with the ergonomics concept application in Traditional Balinese houses. It is conducted by using qualitative descriptive analysis with the application of Tri Hita Karana conception in traditional Balinese houses and also accompanied with ergonomic values based on the subject of the task, and environmental organizations.

\section{DISCUSSION}

Ergonomics comes from two Greek words namely "ergon" and "Nomos" which means work and rules. Ergonomics is an interdisciplinary science that studies the interaction between human beings, objects used and the environmental conditions. Ergonomics is also concerned about the adjustment between the design of equipment and work with human capabilities and limitations. (Mechanical Engineering/Institute of Production Engineering,Work Science/ Ergonomics, 2005). Ergonomics known as science, technology and art to associate tools, methods and environment on human ability, skill and limitations, in order to obtain the working conditions and a healthy environment, safe, convenient and efficient to achieve the highest productivity.

Tri Hita Karana conception is the three causes that lead to happiness or harmony, which can be achieved if there is harmony of human relationships with God, amongst human beings and human beings with the environment. Tri Hita Karana is the trilogy concept of life in which God, man and nature stood at each corner as the absolute elements of the implementation of universe breath. World universe is divided into three parts of natures. First, parahyangan nature is well known as God nature. Second, pawongan nature is well known as human nature in which men hold her life in physical and spiritual dimensions. Third is the palemahan nature that is the universe under the degree of human highway, like the world of plants and animals. Implementation of the harmony within human life is actually the absolute harmony of the three dimensional natures. Man must obey and comply with the rules and laws of nature that have been outlined to him through religious teachings that have been revealed by God. Religion derived from Sanskrit a-gama, a means no and gama means chaos.
So agama refers to an instrument or methodology for managing all aspects of human life in order to avoid chaos in life and instead of harmony, tranquility and peace of life can be achieved. Violation of norms and rules of the religion which God has outlined will result in the degradation of human morality that will make man followed the desires to satisfy all the desires of his life regardless of the rules of the norm of life, so it will cause a variety of social and environmental problems. The environment will be exploited by arbitrarily without taking into account environmental governance that resulted in deterioration of the environment on human carrying capacity, and the result will be disaster arising everywhere as revenge against the human nature.

\section{Task, Organization and Environment}

As a multidisciplinary science, which integrating the various elements of science, such as physiology, anatomy, health, technology, design and other disciplines related to the job, ergonomics is aim at (Manuaba, 1998) (a) the improvement of physical and mental prousperity; (b) the improvement of social welfare, (c) the rational balance between human or human-system equipment with the technical aspects such as economics, anthropology, and culture.

To implement the above objectives need rests on the capability, skill and human limitations, with consideration to the task, and environmental organizations, as well as the effect caused to the body. The ideal objective is to regulate these activities are within the limits where people can tolerate it, without causing disorder (Manuaba, 1998).

Task or activities in interior will result on others facilities. Activities in traditional Balinese society when it is connected with lounge facilities embodied in traditional Balinese buildings will be facility buildings that form the nine pillar of Balinese building (bale tiang sange), Balinese buildings with 4 pillars (bale sakepat/bale sumanggen)and (umah meten) bedroom. Three buildings (bale tiang sanga, bale sikepat, bale sekenam) is an open building. In the middle of the house there is natah (court garden) which is the center of the house. The inside of the house is for family head's bedroom, or the daughters. The bedroom is a building that has four walls, in accordance with the functions that require high 
security compared to other spaces (where essential goods \& securities), jineng (Balinese rice granary) to store rice and paon (Balinese kitchen) as the place of cooking activity. As explained by Padmanaba (2006) that the building of traditional houses in Bali are used during the Hindu ritual such as Panca Yadnya like activity such as Manusa Yadnya; Rsi Yadnya; Pitra Yadnya and daily activities of other everyday.

Facilities that can be found in the building, eg on the bed inside of bale meten, cooking stove in the kitchen or paon. The measures of those tools are highly adapted to the size of the user, so the attitude of forced or unnatural postures can be reduced. Similarly, in another section, such the steps to the bedroom and the height of opening the door are using the anthropometric measure of user. As proposed by Kagami (1988), a researcher of Traditional Balinese Architecture (TBA) from Japan in Padmanaba (2006) revealed that TBA have implemented ergonomics 'human factor' in the planning process of building homes.

Organizations in ergonomics discuss how things are organized activity, whether time, place and others. Organizing activities on traditional Balinese building are very clearly referring to the basic concept of Tri Loka (the three part of natures), or Tri Angga (the three parts of spaces). Tri Loka is about the concept of hierarchy of space; Nawa Sanga or Sanga Mandala concept of orientation is about cosmology; Manik Ring Cucupu cosmology is the concept of balance; concept of human proportions and scale; concept courts, open water; concept of honesty of construction materials. Whereas the concept of Tri Angga is the basic concept is closely related to the planning architecture, which is the origin of Tri Hita Kirana. The concept of Tri Angga divide nature into three parts or spaces, namely: 1) Nista (bottom, dirty, feet); 2) Madya (middle, neutral body), and 3) Utama (top, head). There are three axes that are used as guidelines for the arrangement of buildings in Bali, the axes were among others: 1 ) The axe of cosmos: Bhur, Bhuwah and Swah (hidrosfir, litosfir and atmosphere), 2) The axe of rituals: Kauh Kangin (the rising and setting of the sun), 3) The axe of natures: Kelod Kaja (mountains and sea). Physical transformation of these concepts in architectural design is a reference to the arrangement of a typical residential room in Bali. Thus, by the arrangement of the re- gions north for sacred building, Utama/ulu (main) and the last/ west or teben is in the area of rebuke, place is for pets.

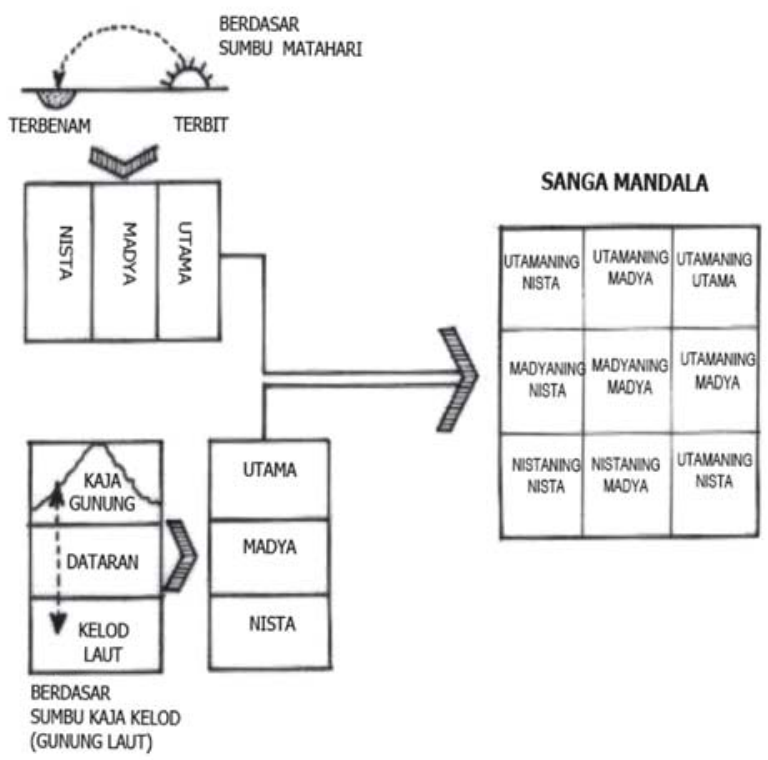

Source: Eko Budiharja (1986) on Acwin (2003)

Environment is very concern in the discussion of ergonomics. If the activity in environment does not meet the requirements, it may affect to the occupational health that can lead to accidents (occupational accidents), diseases due to labor and employment due to illness (occupational disease and work related diseases). Work environment that need to be considered are temperature, humidity, where the work is carried out, consisting of a slope, the height of the workplace, and others. In addition, the physical environment to be aware of the social environment also must obtain the appropriate portion. In addition, social environment is about customary, customs, norms, taboos and so forth.

Physical environment in a traditional Balinese building almost have the same attention to the ergonomics point of view, which need emphasis is the social environment, where taboos, customs and beliefs are placed. Ergonomically activity and the demands posed facility would never be realized if it is contrary to the custom, taboos and beliefs that exist in one place. Moreover, it has developed a participation ergonomics study that means the involvement of any individual or team, which expected not only physical but also thoughts and feelings. The task of this team begins with the search of the implementation issues, 
and evaluation of the existing shortcomings. So we will get an optimal solution, systems and products of human labor, high quality, competitive and sustainable in accordance with the wishes of all parties. In this case the whole teams, will be actively involved in solving problems and discussing about time, types, the best way of application, amount and cost of interventions to be implemented. Through the method, a local reference which appears in this case can be either customs, beliefs or religious background concept, which eventually became the guidelines in the activities and ultimately manifested in the facility or any other embodiment.

\section{Human relationships with God, neighbor, and the Environment}

The three relationships in interior are applied to the circulation. There are three alternatives, such as the elements that formed the space, supported space of building, facility, utility, and decoration. Human relationship with God can be seen clearly by the three alternatives that lead to the posting of the sacred building or temple on the main areas, which in this case lies in the northeast region which followed by other buildings that lead to the area southwest of the site. There are three alternatives horizontally which refers to the concept of Tri Mandala, which consist of Utama Mandala (holy place), Madya Mandala (the place of doing activity) and Nistha Mandala (the place of public services). In the matter of the linkage portion of the building, low height are related to horizontal or hierarchy of a building that refers to the concept of Tri Angga consisting of: head, body and legs. It can be seen clearly that the circulation is directed to areas with the aim to facilitate a relationship with God. In this case the circulation is so constructed that residents can easily carry out religious rituals every day. For example the circulation is so constructed on the access from the kitchen to the shrine so that easy and no obstacles in ritual purposes called mebanten saiban which is conducted every morning. Walls, windows and door openings are not made perpendicular to the other openings exist, moreover with the entrance to the family temple. It is closely related to efforts of eliminating undesirable cross circulation and also to the arrangement of circulation and also with the entrance which did not match to entrance of sanctuary area which is purified. The facilities and decoration always will con- sider sacred right as a reference, for example, that the placement of the bed will put the head in the direction in which sacred or temple area, and not vice versa. Utilities in this case are represented by more dirty water disposal is also placed opposite the shrine. So the dirty water discharge leads to the southwest region.

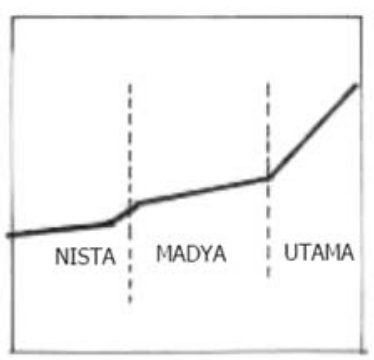

TRI LOKA/TRI ANGGA

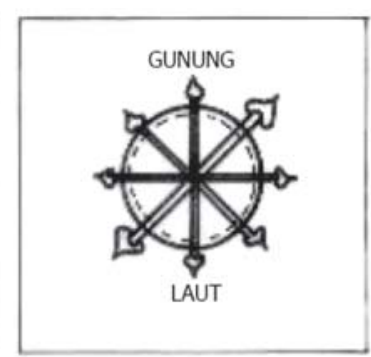

NAWA SANGA/SANGA MANDALA

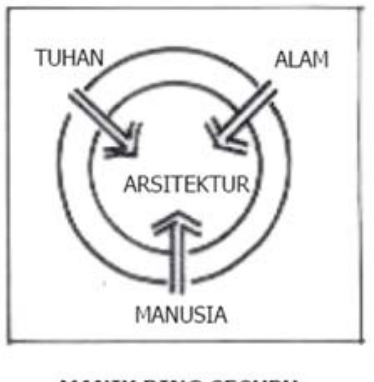

MANIK RING CECUPU

Source: Eko Budiharja (1986) on Acwin (2003)

Relationships with amongst human beings represented by the friendliness of the opening in the middle of a residential area called as natah (court garden) which is the center of the dwelling. And the door (angkulangkul) into a very giving an impression invited to entrance, but there are also wall called aling-aling, which functions as a filter to the direction of view in order give more privacy in the areas. To these two points in a row as it serves to build relationships with fellow residents, with welcome marked with entrance to attract attention, and the presence of open spaces in residential centers, which signifies openness, also for man's relationship with one another. From the concept of Nawa-Sanga point of view natah located in the area of Madya-Ning-Madya, a region that is very human, which is the orientation center and the center of circulation. In natah, all human activity converged, such as what Ashihara analyzed as a centripetal order. Where natah is a large space that unites the pillar of uma meten (bedroom) on one side and bale sanga (Balinese building with 9 pillars), bale sakepat (Balinese building with 4 pillars), bale 
sekenem and natah as well as an appropriate house. The same house as presently where bale-bale is a bedroom, natah as a place of gathering could be called the family room. When linked to it further, the paon (kitchen) activity can be equated with cooking and dining, so the Balinese traditional house, apparently identical with the form of West'flats.

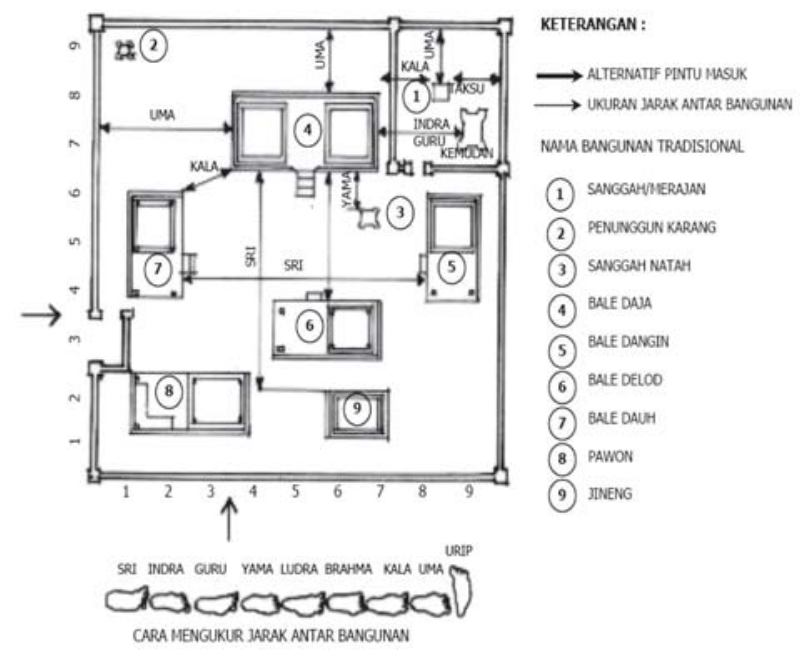

Source: Eko Budiharja (1986) on Acwin (2003)

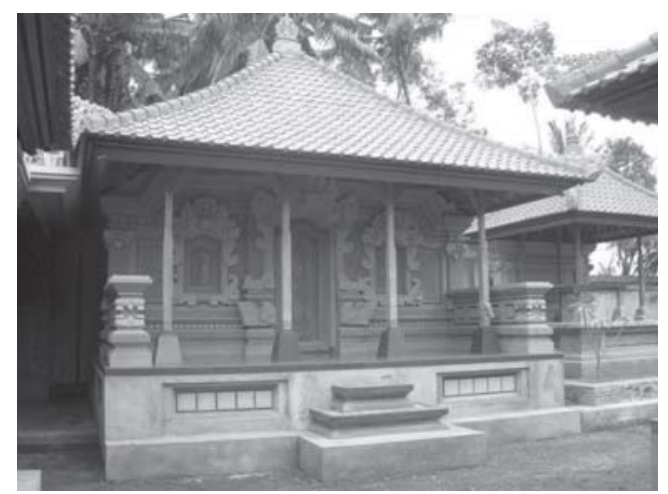

Picture 1. Bale Daje

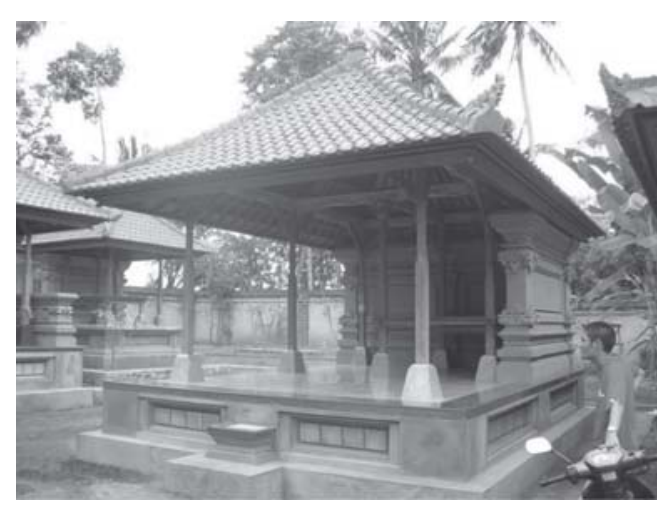

Picture 2. Bale Dangin

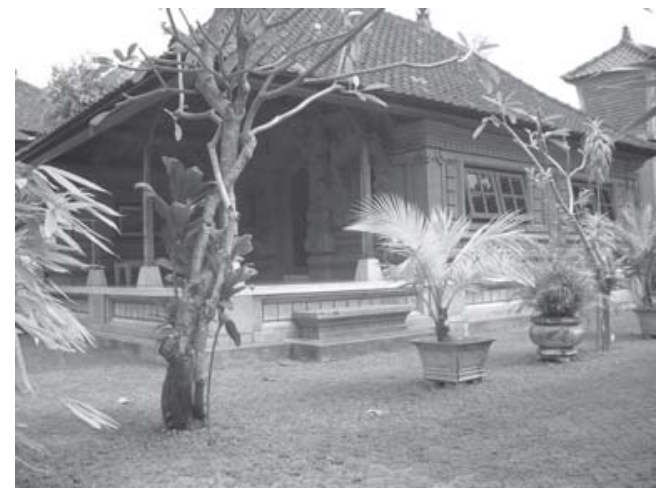

Picture 3. Bale Dauh

Human relationships with environments are characterized by the utilization of environmentally positive potential maximum. For example, the maximum utilization of the activity on the sun terrace which can enter umah meten (bedroom) through a full day without the glare and the lack of light. Air circulation is done by placing wall openings so that the circulation can lead comfortless. The placement of space between the buildings mass is very concerned on the rainy and dry seasons in each year, so that air flow can be utilized effectively.

\section{CONCLUSIONS}

Based on the study, we can conclude several things as follows: 1) during the embodiment of traditional Balinese houses, things to be considered are: the relationship between human beings with God, amongst human beings, and the relationship between human being with the environment. It has also a consideration in ergonomics which consisting of task, organization and environment; 2) in general, the concept of Tri Hita Karana has similarities with the concept of ergonomics in traditional Balinese buildings. Once the world's influence on traditional communities is increase, we need a wise and prudent action from all parties to get involved in protecting the wealth that has been passed down by generations, as the concept of traditional Balinese buildings which should be maintained and preserved.

\section{REFERENCES}

Acwin, D. N K. (2003), Perumahan dan Pemukiman Tradisional Bali, Jurnal Pemukiman “ Natah” Vol. 1 NO: 1. Februari 2003. 
Green, W.S., Barnet, C.S. (1993), Design Implications of the Manual Handling Regulation and Code of Practise in Australia. Proceedings of the International Ergonomics Association World Conference on Ergonomics of Materials Handling and Infomation Processing at Work, Warsaw, Poland, 1417 june 1993.

Houshyar, A. (1993), Appication of Ergonomics to a Material Handling Problem. The Ergonomics of Manual Work, Proceedings of the International Ergonomics Association World Conference on Ergonomics of Materials Handling and Infomation Processing at Work, Warsaw, Poland, 14-17 june 1993. 41-48.

Mechanical Engineering/Institute of Production Engineering Work Science/ Ergonomics. (2005), Work Science / Ergonomics - What Is It?. http:// 141.99.140.157/d/aws/index.htm. access 02/01/06

Macinkowski, J.S. (1993). Ergonomic Requirement for The Forming of Work Environmental Condi- tions in The Potato Industry. The Ergonomics of Manual Work, Proceedings of the International Ergonomics Association World Conference on Ergonomics of Materials Handling and Infomation Processing at Work, Warsaw, Poland, 14-17 june 1993. 697-700.

Manuaba, A. (1998), Bunga Rampai Ergonomi: Vol I. Program Pascasarjana Ergonomi-Fisiologi Kerja Universitas Udayana, Denpasar.

Manuaba, A. (2005), Total Approach in Evaluating Comfort Work Place. Preseted at UOEH International Symposium on Confort at The Workplace. Kitakyushu, Japan, 23-25 Oct 2005.

Michelle M. Robertson. (2005), Macroergonomics: A Work System Design Perspective. http:// www.ergonomie-self.org. Access 1/24/2006

Padmanaba, CGR. (2006). Asta Bhumi dan Asta Kosala Kosali. Buku Ajar PS Desain Interior. FSRD ISI Denpasar. 